\title{
Understanding the Concept of Information Literacy Students - For Example, the City Library "Don Mihovil Pavlinovic" Imotski
}

\author{
Marija Jovic \\ Public Library "Don Mihovil Pavlinovic", Croatia
}

Copyright (C) 2016 by authors, all rights reserved. Authors agree that this article remains permanently open access under the terms of the Creative Commons Attribution License 4.0 International License

\begin{abstract}
This paper presents the results of a study on the understanding of the term information literacy of primary and secondary school students, from the fifth grade of elementary school to the fourth year of high school at the local level, and who are members of the City Library in Imotski. The study examined 98 members of the City Library, through a questionnaire with a total of 25 questions. The selected sample consists of primary and secondary school students, members of the City Library because of their availability. The main objectives of our study were; to investigate, analyse and determine how many students is information literate. That is, if students at the age of eleven to eighteen years understand the concept of information literacy in the right way. Since the misunderstanding of the term information literacy of students is present in the increased percentage, a measure is proposed of ongoing professional development of students in the spirit of the European concept of education.
\end{abstract}

Keywords Information Literacy, Virtual Reality, Students

\section{Introduction}

Our study should serve teachers, but also to other; parents, students and librarians ... as participants in the formation of personality traits in young people as aid in decision making during training and information for successful information literacy of students.

The emphasis was on acquaint one wider range of the public with basic information literacy concepts, but with a focus on information literacy of students as one of the important links to the impact of technology on the development of society as a whole.

Resisting the inevitable development of the technology, the library is trying to install as many as possible to children, and therefore leave the value of the written book. We are witnessing, however, that the younger generation of students are highly skilled in using the internet and fairly information literal. On the one hand that is good, but on the other hand the problem arises, where such literacy has went so far as to pupils to "download" books from the web. Students therefore read less and plagiarize more in the modernized world.

That is why we say, and rightly so, that new technologies are both the aforementioned and have also enabled, pointing us to a number of legal, ethical and even philosophical issues in the field of humanities and social relations.

Many students, in fact, in the aforementioned age category confuse the concepts of information and computer literacy, thinking if they use a computer that they are automatically information literate. In doing so, they do not know the concepts such as Boolean operators and Google Scholar. Pupils' lack of understanding of the term information literacy leads them astray and even opens a new topic on the dangers of (un)awareness with which students often encounter on the Internet because of ignorance.

In this sense the ongoing information education in schools should be improved. An important determinant of new educational programs should be a forming of a council for education on the level of primary and secondary schools in Imotski that would take care of the ongoing education and training of students primarily, but also teachers and librarians - key holder of the educational system changes.

In writing and drafting this paper we also used the method of comparison, so we consulted the cited literature, with which we compared the possible approaches to facilitate drawing conclusions. By using the method of generalizing as a methodical thought process we observed and understood the general through individual and special.

The purpose of our study was therefore to better explain to students of information literacy in order for them to better understand the term. 


\section{Methodology-Sample}

In the City Library a 541 member is registered $(\mathrm{N}=541)$ from the area of Imotski region and Herzegovina. Because the study involved 98 pupils, members of the City Library in Imotski, $18.1 \%$ of the studied population is involved.

The survey was conducted during November and December of 2013. Participation in the survey was voluntary with prior consent and agreement with the students' parents, because of their immaturity. Participants were guaranteed anonymity. At the start of the survey the respondents were read a brief verbal instruction and explained the purpose of the study.

In the group of study respondents the representation of male students was $17.3 \%(\mathrm{~N}=17)$, females $82.7 \%(\mathrm{~N}=81)$. Minimum age of study respondents was 10 years and the maximum 18 years.

Table 1. Gender structure of subjects

\begin{tabular}{|c|c|c|c|c|}
\hline & Frequency & Percentage & $\begin{array}{c}\text { Valid } \\
\text { percentage }\end{array}$ & $\begin{array}{c}\text { The } \\
\text { cumulative } \\
\text { percentage }\end{array}$ \\
\hline $\begin{array}{c}\text { The } \\
\text { female } \\
\text { students }\end{array}$ & 81 & 82.7 & 82.7 & 82.7 \\
\hline $\begin{array}{c}\text { The male } \\
\text { students }\end{array}$ & 17 & 17.3 & 17.3 & 100.0 \\
\hline Total & 98 & 100.0 & 100.0 & \\
\hline
\end{tabular}

Source: The research of the author, 2013

Statistical analysis of the age structure of respondents identified two categories. The first category consists of primary school students aged $10-14$ years $(33.7 \%, \mathrm{~N}=33)$, the second category consists of students in the 15-18 years $(66,3 \%, \mathrm{~N}=65)$.

Table 2. The age structure of subjects

\begin{tabular}{|c|c|c|c|c|}
\hline Age & Frequency & Percentage & $\begin{array}{c}\text { Valid } \\
\text { percentage }\end{array}$ & $\begin{array}{c}\text { The } \\
\text { cumulative } \\
\text { percentage }\end{array}$ \\
\hline $\begin{array}{c}\text { From } \\
10-14\end{array}$ & 33 & 33.7 & 33.7 & 33.7 \\
\hline $\begin{array}{c}\text { From } \\
15-18\end{array}$ & 65 & 66,3 & 66,3 & 66.3 \\
\hline Total & 98 & 100.0 & 100.00 & \\
\hline
\end{tabular}

Source: The research of the author 2013.

\section{Data Processing}

In this study, a total of 98 questionnaires was collected and processed. Processing of the results was performed using the statistical functions within the computer program Statistics for Windows.

\section{The Theoretical Approach to Information Literacy - A Brief Overview of the Advantages and Disadvantages}

Špirenec [4], states that the teacher is no longer the sole provider of information. He integrates various sources into the learning process to encourage the following skills:
1. Accessing a variety of educational resources without the intervention of teachers

2. Selection and analysis of sources

3. The use of resources for different purposes

4. Management of information

5. Use of knowledge centres such as libraries, museums and archives

The term covers a wide range of sources of information carriers such as sources on paper, computer materials, network resources (online courses, conferences), mixed media (audio, video, slides, TV), etc.

The beginnings of communication sciences can be identified in the early discussions on the appearance and meaning of the periodic press, sometime in the 17 th century. Linguists, lawyers, historians, moralists discussed the new phenomenon that has received increasing importance in people's lives. In Europe in the sixties of the 20th century human sciences are mainly interdisciplinary engaged in media and communication media.

Without interfering too much in history, in this study, and in this particular case, however, information literacy of students will be discussed, and in this connection the communication processes that take place using a new kind of media.

Tomić [6] clarifies the word Cyberspace that came in daily use as a coin from the science fiction novel Neuromancer W. Gibson, from 1984. It can be compared to the Land of $\mathrm{Oz}$, with the difference, that besides the great wizard and a little girl from Kansas who have exclusive experience of $\mathrm{Oz}$, cyberspace receives all interested underneath its wing to venture into the world of virtual reality, enabled by computer technology. Cyberspace is actually an artificially created environment, created by the computers. Cyberspace is an artificial, virtual reality that is created and reproduced by computer systems

Perhaps the very study of information literacy in students is an opportunity to pause and consider, if children are not given too much momentum and if it is not the time to set certain boundaries to them who are only formed in the figures in that endless world of virtual reality.

Špiranec and Banek [5] further state that the information literate persons are defined as: those who have learned how to learn because they know how knowledge is organized, how to find information and how to use them in a completely understandable way. The acquisition of generic competencies allows the student:

- to be aware of the information needs,

- to recognize information that can solve the problem,

- to find the necessary information,

- to value the information,

- to organize the information,

- to effectively use the information

We need to distinguish computer literacy from information literacy. Under the term literacy we understand the use of computers, hardware and software, networks and 
applications. Information literacy - is focused on content that is transferred with technology.

Aparac [1] argues in the article "Informational sciences that when talking about the impact of computers and telecommunications on information activities, it is necessary to highlight the emergence of a number of new organizational, political, legal, ethical and economic problems caused by computerized and networked systems. But on the other hand, he indicates the unjustified neglect of the philosophical, epistemological, linguistic and similar problems in the field of social and human relations."

\section{Social and Psychological Implications of the Virtual Space}

Tomić [6] by explaining the differences between the Internet and other audio visual media says that unlike television that broadcasts its messages to a passive and isolated audience, the Internet involves interaction, and depends directly on the user. Since the common sources of information and social cooperation constitute the conditions of successful communication, the defenders of the new technology believe that it is the internet the link that will allow for the reintegration of society, seriously weakened by the influence of television. Pointing to the fact that cyberspace is encouraging the formation of "virtual communities", freed of national or geographical units; they see the Internet in the true sense of the word renaissance "free speech". It can often be heard that we live in a civilization where there is more information and less and less sense. This can be explained in a way that the information is not able to compensate for the loss of meaning. Despite increasing IT network that multiplies the contents, deterioration of meaning occurs more rapidly since its re-injection. Instead to create communication, information is exhausted by staging the communication. Instead of producing meaning, it exhausts itself in the staging of sense.

Each participant of virtual communication should be aware of the dangers that such communication can have. Experts warn of the dangers of everyday virtual communication, especially for minors. Parents know that the child has access to the Internet, but do not really know what the child does on the internet and which sites it visits.

Recently [2] http://www.ezadar.hr/ 20.04.2014) the portals come out with interesting data that confirm the aforementioned thesis. Facebook has 276,220 users in Croatia between the ages of 13 and 17 . The only problem is that in this age group in Croatia only 250,000 are children. This means that many of them, at least 25,000, are younger than thirteen years and have falsely presented themselves. According to the rules of Facebook, the minimum age to participate in this social network is 13 years old. However, there is no system of quality control, so it is enough that a child of any age fakes its date of birth and creates a profile with no problem. According to the official results of a study [3] (http://www.vecernji.hr/regije/maloljetnici 20.04.2014) in Croatia, as many as $18 \%$ of juveniles shall contact unknown people and give them their most intimate details.

\section{The Results of the Study}

There are a total of 76 information literate children covered by the sample, which represents $77.6 \%$ of the studied population

Table 3. Information literate children

\begin{tabular}{|c|c|c|c|c|}
\hline & Frequency & Percentage & Valid percentage & The cumulative percentage \\
\hline The information literate & 76 & 7.6 & 7.6 & 77.6 \\
\hline The information illiterate & 22 & 2.4 & 2.4 & 100.0 \\
\hline Total & 98 & 100.0 & 100.0 & \\
\hline
\end{tabular}

Source: The research of the author 2013.

The study found that the information literate children on the population of members of the City Library is somewhat more at the age of $15-18$ years, $57.9 \%(\mathrm{~N}=44)$ as well as was expected. Younger children still have limited access to the Internet and less need for it.

Table 4. The information (i) literate persons by age structure

\begin{tabular}{|c|c|c|c|c|}
\hline Information literate & Frequency & Percentage & Valid percentage & The cumulative percentage \\
\hline From 10-14 & 32 & 42.1 & 42.1 & 42.1 \\
\hline From 15-18 & 44 & 57.9 & 57.9 & 100.0 \\
\hline & 76 & 100.0 & 100.0 & \\
\hline Information illiterate & & & & 68.2 \\
\hline From 10-14 & 15 & 68.2 & 68.2 & 100.0 \\
\hline From 15-18 & 7 & 31.8 & 31.8 & \\
\hline & 22 & 100.0 & 100.0 & \\
\hline Total & 98 & & & \\
\hline
\end{tabular}

Source: The research of the author 2013. 
Information written in a high percentage, $67.1 \%(\mathrm{~N}=51)$, also read books and do required reading on the Internet.

Table 5. Percentage of doing required reading on internet

\begin{tabular}{|c|c|c|c|c|}
\hline & Frequency & Percentage & Valid percentage & $\begin{array}{c}\text { The cumulative } \\
\text { percentage }\end{array}$ \\
\hline & & & & 67.1 \\
\hline Doing required reading over the internet & 51 & 67.1 & 67.1 & 100.0 \\
\hline $\begin{array}{c}\text { Not doing required reading over the } \\
\text { internet }\end{array}$ & 25 & 32.9 & 32.9 & 100.0 \\
\hline Total & 76 & 100.0 & \\
\hline
\end{tabular}

Source: The research of the author 2013.

\section{Conclusions}

Internet is present in almost every home because life without a personal computer connected to the Internet is almost unimaginable. It is not surprising that socialization through social networks has today become a phenomenon that has spread across the world. On the Internet you can find almost everything that the students are interested in, so it is no surprise that many of them read books and and do required reading across the web.

With the arrival of new media, communication and communication processes began to change. The truth is that today people spend a lot of time on the computer. And although virtual communication has its advantages, some of which are contacts with people dear to us that we do not see often, it is impossible to ignore the negative aspects of virtual communication. In a sea of virtual identity is very easy to lose track between virtual and actual reality. In virtual reality, anyone can choose an identity that he/she pleases, to become the person they want. With that we change the default settings that apply in communication face-to-face, where a person stands in front of us, and we ourselves do the selection based on what we see and how we perceive the person next to us. People are often not aware of the dangers of such communication. Here I particularly think of the minors that often approach various sites and social networks, and without even reading the privacy policy, leaving their private information visible to everyone and coming into contact with complete strangers.

Most parents know that their children visit various sites, but they do not know what they do or what their children engage in on those sites.

A large number of young people in our study consider being information literate, just because they know to use the social networking portals and visits sites to help them in their education. So with as little effort and time they acquire the necessary data, without checking their relevance.

Although it is difficult to predict how the world of social networks and information literacy will look like in five or ten years, one thing is certain - the type of social interaction and communication and the provision of data which now serves humanity will not disappear.

In the sea of all the relevant information that are offered to us, only relevant information lost its value somewhere along the way. We are often bombarded with "insignificant" information, and less instructive, practical information that we can use in life. We need to ask ourselves just how good the fact that the world is becoming a global village. A quick and easy obtaining of information is often not the best way, and children need to be educated in that direction.

Another thing to be mentioned when it comes to virtual communication and that is alienating people from one another. Although it seems that by using virtual communication and social networks we have become more informed and "smarter", the fact is that the virtual world is not and will never be able to replace human contact.

And finally, we should not neglect the value of written material, which is stored on the shelves of libraries. No matter how much you are information literate and how skilfully we use the browsers on the Internet, a librarian and a book that he offers with its human touch from the shelves can undoubtedly be of great help.

\section{REFERENCES}

[1] Aparac, T. (03.12. 2013). „Information sciences: basic concepts and problems , $<$ http://www.ffzg.unizg.hr/infoz/bi blio/nastava/dz/text/iztkp.htm> (15.04.2014).

[2] (09.02.2011).

http://www.ezadar.hr/clanak/facebook-uvodi-zastitu-maloljet nih-korisnika (20.04.2014).

[3] (09.02.2011).http://www.vecernji.hr/regije/maloljetnici-zbog -drskih-krada-prijavljeni drzavnom-odvjetnistvu-clanak-250373 (20.04.2014).

[4] Špiranec, S., Obrazovanje korisnika u visokoškolskim knjižnicama: novi pristupi u mrežnom okruženju (User education in academic libraries: new approaches in electronic environment), Master thesis, mentor, Lasić-Lazić, Jadranka, Zagreb. University of Zagreb, Faculty of Humanities, pages 17-18, 2005.

[5] Špiranec, S. Banek-Zorica, M. Informacijska pismenost teorijski okviri i polazišta (Information literacy: theoretical framework and starting points), Zagreb: Department of Information Studies, pages 23, 2008.

[6] Tomić, Z., Communicology. Beograd: Čigoja štampa, 6 (2): 209-210, 2003 
[7] asili, C. Theorems of Information Literacy // Informaciona pismenost i doživotno učenje/uredili Vraneš,A. Marković,LJ. Aleksander. G. Beograd: Filološki fakultet Univerziteta Bibliotekarsko društvo Srbije: Emporija univerzitet, 46-78, 2008.

[8] Castells, M. The Rise of the Network Society. Zagreb. Golden marketing, 2000.

[9] Dizdar, S., (plenary papers). Information Literacy and Lifelong Learning // II Counseling of higher education -implementation of the Bologna principles at the University of Sarajevo, Sarajevo, 11. i 12. April 2008.

[10] Information Literacy Competency Standards for Higher Education available at: http://www.ala.org/acrl/standards/inf ormationliteracycompetency, 8. 4. 2012.

[11] Lončar - Vicković, S., Dolaček - Alek, Z., The learning outcomes -manual for university teachers. Osijek. University of Josip Juraj Strossmayer. Available at: (9.4. 2012) $<$ http://www.unios.hr/uploads/49ishodi\%20ucenja_prirucnik $. p d f>.2009$.

[12] Lasić-Lazić, J., Špiranec, S., Banek Zorica, M., Standardizacija u području informacijske pismenosti: između iluzije i potrebe (Standardization in the Information Literacy Domain: Between Necessity and Illusion) / U:
Standardization and quality of library services / [Conference organizer Library Association of Serbia]. -Beograd: Library Association of Serbia, pages 41.50., 2011.

[13] Laszlo, M., Lasić-Lazić, J. Measures of information (il) literacy/: Standardization and quality of library services, / [Conference organizer Library Association of Serbia]. -Beograd: Library Association of Serbia, pages, 65-80, 2011.

[14] Prensky, M. Digital Natives, Digital Immigrants. Do they really think differently? Edupoint. Available at: < http://edupoint.carnet.hr/casopis/32/clanci/2> February, volume V 2005.

[15] Rašidović, B. E.Information literacy and academic libraries-user education, Model of the University of Sarajevo. Sarajevo, Faculty of Humanities, 2011.

[16] Secker, M. "A humanistic approach to information literacy training : the programme at the Commonwealth Scientific and Industrial Research Organisation (CSIRO)",

[17] Rendel J. M. Rockhampton, Laboratory, < http://www.une.edu.au/sat/pdf/CSIROliteracy.pdf >(04.04.2 011).

[18] Tese The thesaurus for education systems in Europe - edition. Available at http://eacea.ec.europa.eu/education/eurydice/tes e_en.php (downloaded 8. 4. 2012), 2009. 